Dr. Thechn. Science, Professor Shalomeev V. A., Dr. Thechn. Science, Professor E. I. Tsivirko, Postgraduate student N. D. Aikin

National University «Zaporizhzhya Polytechnic», Zaporizhzhia

\title{
HIGH-QUALITY MAGNESIUM-BASED ALLOYS WITH IMPROVED PROPERTIES FOR ENGINEERING
}

\begin{abstract}
Purpose. To give a theoretical analysis and a reasonable choice of the main alloying elements for the development of magnesium alloys with a high level of properties.

Methods of research. Metallographic and X-ray research methods. Determination of mechanical properties under tension (GOST 1497-84) and long-term strength at elevated temperatures (GOST 9651-84).
\end{abstract}

Results. It is shown the relationship between the state diagrams and the melting point of the selected alloying elements with the heat resistance of magnesium alloys. Perspective elements for improvement of the heat resistance of Magnesium alloys are $\mathrm{Nd}, \mathrm{Ge}, \mathrm{Ag}, \mathrm{Y}, \mathrm{Sc}, \mathrm{Zr}, \mathrm{Si}$, Ti and $\mathrm{Hf}$. These elements form complex intermetallic phases, differed by topology and morphology. Under their influence macro- and micrograins of metal are grinded and the microhardness of structural components increases.

As the content of alloying elements in the alloy increased, the size of spherical intermetallides grew, general number of the intermetallides increased and the strength and durability of the alloy improved.

It has been established that the heat resistance of Magnesium alloys depends first on the number of thermal resistant intermetallic phase, the content of which related to the melting temperature of alloying elements.

Scientific novelty. Based on an analysis of binary phase diagrams and the atomic-electronic structure of the elements, it was determined a number of alloying elements that provide the best combination of mechanical and heatresistant properties of cast magnesium alloys.

Practical value. The use of new Magnesium alloys with high complex of mechanical properties and heat-resistance increased reliability and durability of structural components and parts used in different industries, such as engineering and aircraft engines manufacture.

Key words: magnesium alloy, alloying elements, structure, intermetallic compounds, mechanical properties, heat resistance, grain grinding.

\section{Introduction}

Development of modern mechanical engineering that in need of component parts, operating at higher temperatures and decreasing of their weight makes the use of light alloys more perspective [1].

Hence, Magnesium alloys with the increased mechanical properties and the heat resistance have become high demand for the ensuring of more safety in operating of machines and mechanisms [2].

There is a great number of studies concerning the influence of alloying elements on physical, mechanical and service properties of Magnesium alloys exist nowadays $[3,4]$. However, the number of works dedicated to an identification of the nature of hardening of these alloys during the process of their alloying and modification, the number of the ones describing structural state of metal is limited.

The ways of obtaining high strength in cast alloys while maintaining sufficient ductility are as follows [5]:

1. Formation of complex alloy solid solution.

2. Creation of an optimal structure after the heat treatment.
3. Strengthening of metals and alloys by disperse particles.

To ensure high mechanical and heat resistant properties of casting Magnesium alloys it is advisable to combine all three methods.

Complex alloyed solid solutions are formated in the result of the dissolubility of the elements in Magnesium with definite proximity of their atomic diameters, which according to Hume-Rothery [6], should be differ not more than $15 \%$. If this rule is not followed, there is a decrease of the binding energy of atoms of the dissolvent and alloying elements and due to the distortion of the crystal lattice of the matrix their dissolubility decreases.

Another important condition of the dissolubility of an element in the metal base according to Darken-Gurry [7], Gschneider [8], Wobbor [9] is a small difference of electronegativity, which should be not more than 0,2-0,4. Analyzing the behavior of Magnesium during alloying by different elements it can be seen that the formation of magnesium-based alloys due to its electropositive nature complicates the creation of metallic compounds.

(C) Shalomeev V. A., Tsivirko E. I., Aikin N. D., 2019

DOI 10.15588/1607-6885-2019-1-8 
Thus, from a variety of elements, only a few of them that have a favorable factor for the ratio of atomic diameter $(<15 \%)$ and electronegativity $(<0,4)$, are able to form solid solutions with Magnesium, hardening it.

To increase the heat resistance of alloy during its alloying it is necessary to make the melting temperature of alloying elements higher than the melting temperature of the alloy basis [10]. Consequently perspective elements for the alloying of Magnesium alloys in order to increase physical and mechanical properties and heat resistance are: $\mathrm{Nd}, \mathrm{Ge}, \mathrm{Ag}, \mathrm{Si}, \mathrm{Y}, \mathrm{Sc}, \mathrm{Zr}, \mathrm{Ti}, \mathrm{Hf}$.

The goal of the present work was to investigate the influence of above mentioned elements on structure formation, mechanical properties and long durability at increased temperatures of casts made from Magnesium alloys ML5.

\section{Research methodology}

Magnesium alloy ML5 (\% wt.: 7,5...7,9 A1; 0,15...0,5 $\mathrm{Mn} ; 0,2 \ldots 0,8 \mathrm{Zn}$ ) was melted in the crucible induction furnace in line with a serial technology. The melt was refined by VI-2 flux (\% wt.: $38 \ldots 46 \mathrm{MgCl}_{2}, 32 \ldots 43 \mathrm{KCl}, 9 \ldots 11 \mathrm{CaCI}$, $\left.5 \ldots 9 \mathrm{BaCl}, 3 \ldots 5 \mathrm{CaF}_{2}\right)$ in the distributing furnace and then the melt was selected by portions with the ladle. The increased additives of corresponding alloying elements were injected $(0 ; 0,05 ; 0,1 ; 1,0 \%$ - for the calculation) to the selected portion of the melt. After ligatures dissolution the melt was again warmed up to $790 \pm 5^{\circ} \mathrm{C}$, the ladle was put down and after 15 minutes the sand-clay forms were fill up with the melt to obtain standard samples with the working diameter of $12 \mathrm{~mm}$. Samples for mechanical test were heat treated in the furnaces in line with the following regime: homogenization at $415^{\circ} \mathrm{C}$ (for 24 hours), cooling in air + aging at $215^{\circ} \mathrm{C}$ (for 10 hours).

Ultimate tensile strength and relative extension of samples were determined at the P5 testing machine at the indoor temperature.

Long-term ultimate strength at the temperature of $150^{\circ} \mathrm{C}$ and the tension of $80 \mathrm{MPa}$ were determined at AIMA 5-2 testing machine on the samples with the working diameter of $5 \mathrm{~mm}$.

Chemical composition of cast Magnesium alloys was checked by «SPECTROMAXx» and «SPECTROMAXxF» optical emission spectrometers, MFS-8 and TFS-36 photoelectric spectrometer, «SPECTRO XEPOS» EDRF spectrometer.

Macro- and microstructure of analyzed alloys were studied by optical microscopy («Neophot 32», «OLYMPUS X 70»), using «Videotest-Structure 5.0» hardware-software complex based on Axiovert 40MAT metallographic microscope.

Quantitative assessment of structural components of the alloy was carried out by the standard method of calculation of volume percent.

Microprobe analysis of the structural components of Magnesium alloys was performed with «JSM-6360LA» electron microscope.

\section{Research results and their discussion}

Chemical composition of Magnesium based alloy of different microalloying types on the content of the main elements is approximately at the same level $(7,6 \% \mathrm{Al}$; 0,28\% Mn; 0,35\% Zn; 0,02\% Fe; 0,005\% Cu; 0,04\% Si).

Macrofractographic research of fractures of castings from pure Magnesium has shown the existence of fragile coarse-crystalline structure. Macrostructure of standard ML5 alloy was noticeably grained, and insertion of alloying elements into the alloy has ensured a matted cryptocrystalline structure of the fracture.

Microstructure of casts made from pure magnesium had homogeneous (fig. 1a). Microstructure of alloy ML5 was represented by д-solid solution with д $+\Gamma\left(\mathrm{Mg}_{17} \mathrm{Al}_{12}\right)$ eutectic and intermetallides $\Gamma\left(\mathrm{Mg}_{17} \mathrm{Al}_{12}\right)$ (fig. 1b). Insertion of alloying elements in the alloy helped to reduce the distance between of the second order dendrites axes (Table 1), the size of the structural components and crushing of the eutectic (fig. 1c).

Alloying of ML5 Si, Sc, Ti, Ge, Y, Zr, Ag, Nd and Hf grinded micrograin by $30 \ldots 40 \%$, increased the microhardness of the structural components, contributed refinement of intermetallic phases. The influence of the elements on the grain grinding was reinforced with the increasing of the atom nuclear charge of these elements inside every subgroup of the periodic system. Thus, the grain of the element of the $4^{\text {th }}$ subgroup ( $\mathrm{Ti}, \mathrm{Zr}$ and $\mathrm{Hf}$ ) was grinded more intensively.

Lamellate and spherical intermetallic phases were in the structure of ML5 alloy. The insertion of studied alloying elements into the base alloy increased the quantity of intermetallides and changed their chemical composition.

At the same time, the insertion of base ML5 alloy of $0,05 \ldots 0,1 \%$ of alloying elements intensively increased number of spherical intermetallides and slightly-lamellate ones. When the content of alloying elements in the alloy is nearly $1,0 \%$ the number of spherical intermetallides inside the grain significantly increased and the increasing of the lamellate intermetallides was intensive that promoted the grain grinding. With the growing of total number of intermetallides the strength of the metal was also increased. Analysis of the distribution of intermetallides by size groups has shown that in the initial alloy ML5 lamellate intermetallides of the size group of $4 . .15 \mathrm{~mm}$ dominated. Spherical intermetallides generally are represented by the following size group 2...11,5 Mm. Analyzed alloying elements displaced the size of inserts to the smallest groups (to 2...7,9 $\mathrm{Mm}$ - for spherical and 2..11,5 $\mathrm{Mm}$ - for lamellate ones). At the same time the increasing of alloying elements in the alloy increased the number of intermetallides with the size fewer than $2 \mathrm{Mm}$ and dicreased the number of intermellides with the size more than $11,6 \mathrm{Mm}$. It is determined that with the increasing of the volume percent of intermetallides (V) in the alloy ML5 the micrograin is noticeably grinded (Fig. 2). 
Table 1 - Characteristics of structural compounds (average value) of ML5 alloy with different alloying elements

\begin{tabular}{|c|c|c|c|c|c|c|c|c|c|}
\hline Element & $\begin{array}{c}\text { Content, \% } \\
\text { wt. }\end{array}$ & $\begin{array}{l}\text { Distance between } \\
\text { second order } \\
\text { dendrites axes, } \mu \mathrm{m}\end{array}$ & $\begin{array}{c}\text { Micrograin } \\
\text { size, } \mu \mathrm{m}\end{array}$ & $\begin{array}{c}\text { Microhardness } \\
\mathrm{HV}, \mathrm{MPa}\end{array}$ & Element & $\begin{array}{c}\text { Content, } \% \\
\text { wt. }\end{array}$ & $\begin{array}{c}\text { Distance between } \\
\text { second order } \\
\text { dendrites axes, } \mu \mathrm{m}\end{array}$ & $\begin{array}{l}\text { Micrograin } \\
\text { size, } \mu \mathrm{m}\end{array}$ & $\begin{array}{c}\text { Microhar } \\
\text { dness, } \\
\mathrm{HV}, \mathrm{MPa}\end{array}$ \\
\hline \multirow{3}{*}{$\begin{array}{c}\mathrm{Mg} \\
99,9 \%)\end{array}$} & \multirow{3}{*}{-} & \multirow{3}{*}{40} & \multirow{3}{*}{300} & \multirow{3}{*}{524} & \multirow{3}{*}{$\mathrm{Zr}$} & 0,05 & 17 & 105 & 1235,3 \\
\hline & & & & & & 0,10 & 16 & 100 & 1265,6 \\
\hline & & & & & & 1,0 & 16 & 70 & 1297,9 \\
\hline \multirow{3}{*}{$\begin{array}{c}\mathrm{Mg} \\
79,9 \%)+ \\
\text { AI }\end{array}$} & 0,045 & 35 & 210 & 582,0 & \multirow{3}{*}{ Hf } & 0,05 & 17 & 110 & 1256,6 \\
\hline & 0,096 & 30 & 200 & 646,7 & & 0,10 & 16 & 100 & 1294,4 \\
\hline & 8,50 & 25 & 170 & 1226,5 & & 1,0 & 15 & 70 & 1321,1 \\
\hline \multirow{2}{*}{ ML5 } & \multirow{2}{*}{0,32} & \multirow{2}{*}{23} & \multirow{2}{*}{140} & \multirow{2}{*}{1257,6} & \multirow{2}{*}{$\mathrm{Si}$} & 0,047 & 19 & 130 & 1276,5 \\
\hline & & & & & & 0,12 & 17 & 120 & 1313,5 \\
\hline \multirow{3}{*}{$\mathrm{Sc}$} & 0,05 & 18 & 120 & 1465,7 & \multirow{3}{*}{$\mathrm{Ge}$} & 0,055 & 19 & 125 & 1233,4 \\
\hline & 0,10 & 17 & 100 & 1547,1 & & 0,095 & 18 & 100 & 1244,6 \\
\hline & 1,0 & 16 & 90 & 1675,0 & & 1,09 & 17 & 90 & 1287,5 \\
\hline \multirow{3}{*}{ Y } & 0,05 & 18 & 130 & 1385,6 & \multirow{3}{*}{$\mathrm{Ag}$} & 0,046 & 18 & 120 & 1227,4 \\
\hline & 0,10 & 17 & 130 & 1451,8 & & 0,12 & 18 & 100 & 1357,2 \\
\hline & 1,0 & 17 & 100 & 1630,0 & & 0,98 & 17 & 90 & 1390,7 \\
\hline \multirow{3}{*}{$\mathrm{Nd}$} & 0,05 & 18 & 120 & 1290,0 & \multirow{3}{*}{$\mathrm{Ti}$} & 0,05 & 18 & 120 & 1265,6 \\
\hline & 0,10 & 17 & 100 & 1390,5 & & 0,10 & 16 & 100 & 1270,7 \\
\hline & 1,0 & 17 & 90 & 1407,6 & & 1,0 & 16 & 100 & 1283,3 \\
\hline
\end{tabular}

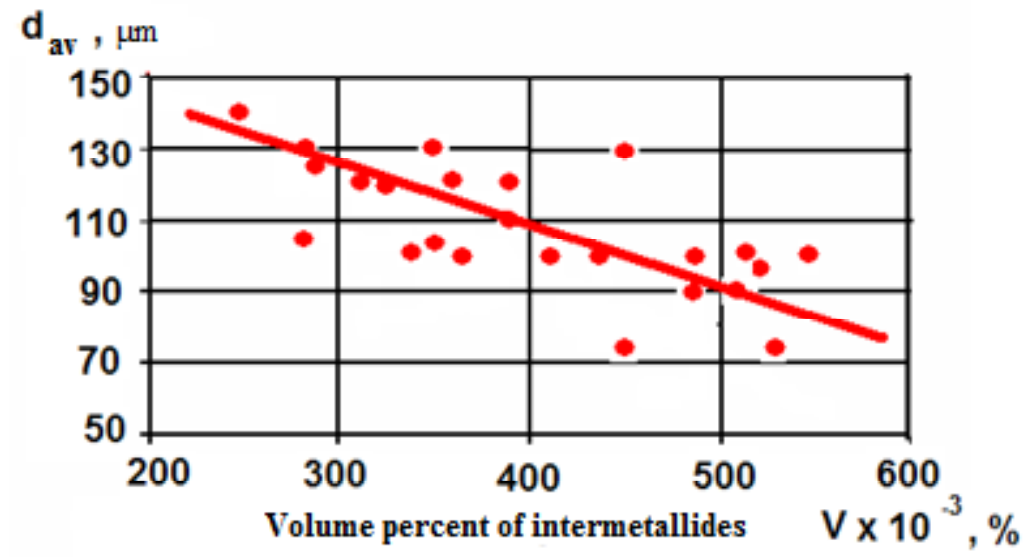

Fig. 2. Effect of volume percent $(V)$ of intermetallides on the size of micrograin $\left(d_{a v}\right)$ in the ML5 alloy

With the growing number of intermetallides the strength and heat resistance of ML5 magnesium alloy also increased. The flexibility of the alloy depending on number of intermellides had non-linear dependence and noticeably increased in volume percent $300 . . .450 \mathrm{r} 10^{-3}$ and decreasing with further growing of their number.

It was determined that both the number of extracted intermetallic phase and its topology and morphology affect on the properties of Magnesium alloy. Lamellate intermetallides smaller than $8,0 \mathrm{Mm}$ and the spherical intermetallides with the size to $11,6 \mathrm{Mm}$ positively influenced on the properties of alloy. Consequently, the spherical shape of intermetallides is more preferable to improve the properties of alloy. A greater hardening of alloy was provided by spherical intermetallides of smaller size groups. Increasing of alloy's flexibility was observed only containing the elements under study at $0,05 \ldots 0,1 \%$, when the share of spherical intermetallides has been increased 
and the grain has been grinded. With a further increase in the content of alloying elements in alloy (1,0\%), simultaneously with the grinding of micrograin the number of intermellides significantly increased leading to embrittlement of the metal and reducing of its flexibility.

The effect on the strength of the alloy (from maximum to minimum) alloying elements are distributed in the following series of Zr, Hf, Sc, Nd, Si, Ge, Ti, Ag, Y (Fig. 3). As the content of $0,05 \ldots 0,1 \%$ by weight of input elements was increased the ductility of the alloy was also growing. The ductility of ML5 alloy at 0,05...0,1 wt \% Y, Ti, Sc, Nd, Hf, markedly improved and $\mathrm{Si}, \mathrm{Ge}, \mathrm{Ag}$ was less improved.

Heat resistance of ML5 alloy was markedly increased with the growing of melt-ing temperature of alloying elements and their content from Germanium to Hafnium.

New magnesium alloys have been developed on the base of this research, which obtained increasing mechanical properties and heat-resistance that are tested on a number of industrial engineering enterprises of Ukraine.

Conclusions

1. On the basis of two criteria (a proximity of atomic diameters $<15 \%$; an electronegativity $<0,4$ ) the alloying elements that positively affect the structure and properties of the cast of ML5 magnesium alloy have been defined. Perspective elements for improvement of the heat resistance of Magnesium alloys are $\mathrm{Nd}, \mathrm{Ge}, \mathrm{Ag}, \mathrm{Y}, \mathrm{Sc}, \mathrm{Zr}$, $\mathrm{Si}$, Ti and $\mathrm{Hf}$.

2. It has been shown that $\mathrm{Sc}, \mathrm{Ti}, \mathrm{Ge}, \mathrm{Y}, \mathrm{Zr}, \mathrm{Si}, \mathrm{Ag}, \mathrm{Nd}$ and Hf in Magnesium alloys form complex intermetallic phases, differed by topology and morphology. Under their influence macro- and micrograins of metal are grinded by $30 . . .40 \%$ and the micro-hardness of structural components increases. With the increasing of the content of every element in the alloy $(1,0 \%)$, its durability also increases while its ductility increases only at the level of $0,05 \ldots .0,1 \%$. At the same time Zr, Hf, Sc significantly strengthen the alloy and Y, Ti increase its durability. Scandium and Neodium simultaneously improve these two criteria of properties.

3. It has been established the influence of the size of the intermetallic phase, its morphology and topology on mechanical properties of the cast from Magnesium alloys. In ML5 alloy with Sc, Ti, Ge, Y, Zr, Si, Ag, Nd and Hf at the level of $0,05 \ldots 0,1 \%$ spherical intermetallides were formed, grinding grain, and increasing the plasticity of the metal. As the content of alloying elements in the alloy increased up to $1,0 \%$ the size of spherical intermetallides grew, general number of the intermetallides increased and the strength of the alloy improved.

4. It has been established that the heat resistance of Magnesium alloys depends first on the number of thermal resistant intermetallic phase, the content of which related to the melting temperature of alloying elements.

5. The use of new Magnesium alloys with high complex of mechanical properties the heat-resistance increased their reliability, durability and safety of the operations of mechanical engineering.

\section{References}

1. Улучшенные магниевые сплави для деталей ГТД / В. О. Богуслаев, П. Д. Жеманюк, В. А. Шаломеев и др. // Коллективная монография под ред. В. О. Богуслаева, Запорожье : «Мотор Сич», 2016. - 259 с.

2. Богуслаев В. А. Авиационно-космические материалы и технологии / В. А. Богуслаев, А. Я. Качан, Н. Е. Калинина. - Запорожье : АО «Мотор Сич», 2009.

3. Rourke D. J. Magnesium-current status and future prospects, Proc. Intern. Magnesium Conf. in conjuction with METER 2000: Magnesium New Business Opportunies / Rourke D. J. - Brescia, 2000. - P. 14-23.

4. Настоящее и будущее магниевых сплавов в нашей цивилизации / Х. Диринга, П. Майер и др. // Литейное производство. -2006 . - № 1. - С. 4-7.
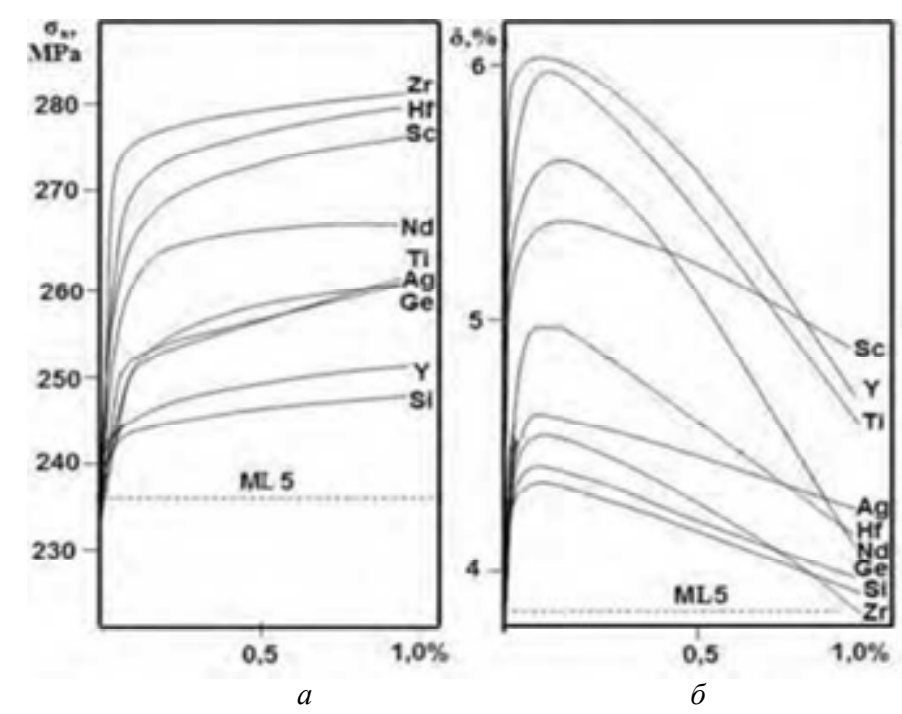

Fig. 3. Influence of alloying on strength $(a)$, ductility $(b)$ and heat-resistance $(c)$ of ML5 alloy (the level of base alloy properties is indicated by a dotted line) 
5. Корнилов И. И. Физико-химические основы жаропрочности сплавов / Корнилов И. И. - М. : АН СССР, 1961. $-212 \mathrm{c}$.

6. Development of new casting magnesium based alloys with increased mechanical properties / V. Shalomeev, E. Tsivirco, Y. Vnukov and etc. // Eastern- European Journal of Enterprise Technologies. - 2016. - 4/1 (82). - P. 4-10.

7. Shalomeev V. A. Influence of titanium, zirconium, and hafnium on the structure and heat resistence of alloy ML5 / V. A. Shalomeev, E. I. Tsivirko, N. D. Aikin // XVII International scientific conference $\ll \mathrm{New}$ technologies and achievements in metallurgy, material engineering and production engineering»): collective monograph edited by J. Boryca, R.Wyczyikowski, N 56, Poland, Czкstochowa, 2016. - P. 471-475.

8. Гшнейдер К. А. Сплавы редкоземельных металлов / Гшнейдер К. А. - М. : Мир, 1965. - 185 с.

9. Уоббер Дж. Металлургия и металловедение плутония и его сплавов / Уоббер Дж. - М. : Госатомиздат, 1962. $102 \mathrm{c}$.

10. Григорович В. К. Жаропрочность и диаграммы состояния / Григорович В. К. - М. : Металлургия, 1969. - 323 с.

Одержано 10.06 .2019

Шаломсєв В. А., Цивірко Е. І., Айкін М. Д. Високоякісні сплави на основі магнію з поліпшеними властивостями для машинобудування

Мета роботи. Дати теоретичний аналіз і обгрунтований вибір основних легуючих елементів для розробки магнісвих сплавів з високим рівнем властивостей.

Методи дослідження. Металографічний і рентгенівський методи дослідження. Визначення механічних властивостей при розтягуванні (ГОСТ 1497-84) і тривалої міџності при підвищених температурах (ГОСТ 9651-84).

Отримані результати. Показано взаємозв'язок між діаграмами стану і температурою плавлення обраних легуючих елементів з жаростійкістю магнієвих сплавів. Перспективними елементами для поліпшення жаростійкості магнієвих сплавів $є \mathrm{Nd}, \mathrm{Ge}, \mathrm{Ag}, \mathrm{Y}, \mathrm{Sc}, \mathrm{Zr}$, Si, Ti i Hf. Ці елементи утворюють складні інтерметалідні фази, що відрізняються топологією і морфологією. Під їх виливом подрібнюються макро- і мікрозерна металу, збільшується мікротвердість структурних компонентів.

У міру збільшення вмісту легуючих елементів в сплаві збільшувалися розміри сферичних интерметалідів $і$ підвищувався загальна кількість надлишкової фази, покрашуючи міџність і довговічність сплаву.

Встановлено, що жароміџність магнісвих сплавів залежить в периу чергу від кількості термостійкої інтерметалідної фази, кількісний вміст якої пов'язане з температурою плавлення легуючих елементів.

Наукова новизна. На основі атомно-електронної будови елементів, аналізу їх діаграм стану подвійних систем з магнісм визначено ряд легуючих елементів, які забезпечують краще поєднання механічних іжароміцних властивостей ливарних магнісвих сплавів.

Практична цінність. Використання нових магнієвих сплавів з високим комплексом механічних властивостей і жаростійкістю дозволило підвищити надійність і довговічність конструктивних елементів i деталей, які використовуються в різних галузях промисловості, наприклад, у машинобудуванні та виробництві авіаційних двигунів.

Ключові слова: магнієвий сплав, легуючі елементи, структура, інтерметалідні включення, механічні властивості, жаростійкість, подрібнення зерна.

Шаломеев В. А., Цивирко Э. И., Айкин Н. Д. Высококачественные сплавы на основе магния с улучшенными свойствами для машиностроения

Цель работы. Дать теоретический анализ и обоснованный выбор основных легирующих элементов для разработки магниевых сплавов с высоким уровнем свойств.

Методы исследования. Металлографический и рентгеновский методы исследования. Определение механических свойств при растяжении (ГОСТ 1497-84) и длительной прочности при повыменных температурах (ГОСТ 9651-84).

Полученные результаты. Показана взаимосвязь между диаграммами состояния и температурой плавления выбранных легирующих элементов с жаростойкостью магниевых сплавов. Перспективными элементами для улучшения жаростойкости магниевых сплавов являются $\mathrm{Nd}, \mathrm{Ge}, \mathrm{Ag}, \mathrm{Y}, \mathrm{Sc}, \mathrm{Zr}$, Si, Ti и Hf. Эти элементы образуют сложные интерметаллидные фазы, отличающиеся топологией и морфологией. Под их воздействием измельчаются макро- и микрозерна металла, увеличивается микротвердость структурных компонентов.

По мере увеличения содержания легирующих элементов в сплаве увеличивались размеры сферических интерметаллидов и повышалось общее количество избыточной фазы, улучшая прочность и долговечность сплава.

Установлено, что жаропрочность магниевых сплавов зависит в первую очередь от количества термостойкой интерметаллической фазы, количественное содержание которой связано с температурой плавления легирующих элементов. 
Научная новизна. На основе атомно-электронного строения элементов, анализа их диаграмм состояния двойных систем с магнием определен ряд легирующих элементов, обеспечивающих лучшее сочетание механических и жаропрочных свойств литых магниевых сплавов.

Практическая ценность. Использование новых магниевых сплавов с высоким комплексом механических свойств и жаростойкостью позволило повысить надежность и долговечность конструктивных элементов и деталей, используемых в различных отраслях промыиленности, например, в машиностроении и производстве авиационных двигателей.

Ключевые слова: магниевый сплав, легирующче элементы, структура, интерметаллические соединения, механические свойства, жаростойкость, измельчение зерна. 